\title{
EVALUASI EKONOMI DARI PRODUKSI NANOPARTIKEL MAGNESIUM OKSIDA MELALUI METODE SOL-GEL COMBUSTION
}

\author{
Dea Bella Dewary Atika Putri, Asep Bayu Dani Nandiyanto \\ Departemen Pendidikan Kimia, Fakultas Pendidikan Matematika dan Ilmu Pengetahuan Alam, \\ Universitas Pendidikan Indonesia \\ nandiyanto@upi.edu
}

Submitted November 11, 2019; Revised November 15, 2019; Accepted November 26, 2019

\begin{abstract}
Abstrak
Tujuan dari penelitian ini adalah untuk mengetahui kemungkinan kelayakan proyek pembuatan Magnesium Oksida (MgO) metode sol gel combustion dengan melakukan evaluasi dari sisi teknik dan ekonomi. Beberapa parameter evaluasi ekonomi dianalisis untuk menginformasikan potensi produksi nanopartikel $\mathrm{MgO}$, seperti lamanya waktu yang dibutuhkan sebuah investasi agar bisa mengembalikan total pengeluaran awal (PBP), kondisi proyek suatu produksi dalam bentuk fungsi produksi dalam tahun (CNPV), keuntungan proyek dan sebagainya. Hasil penelitian menunjukkan bahwa produksi nanopartikel $\mathrm{MgO}$ sangat prospektif. Analisis teknik untuk meghasilkan 1,38 kg nanopartikel $\mathrm{MgO}$ per hari menunjukkan total biaya peralatan yang dibeli sebesar 91.542,86 USD. Analisis PBP menunjukkan bahwa investasi akan menguntungkan setelah lebih dari tiga tahun. Proyek ini dapat bersaing dengan standar pasar modal PBP karena investasi kembali dalam waktu singkat. Untuk memastikan kelayakan proyek, proyek diperkirakan dari kondisi ideal hingga kasus terburuk dalam produksi, termasuk tenaga kerja, penjualan, bahan baku, utilitas, serta kondisi eksternal (mis. Pajak).
\end{abstract}

Kata Kunci : nanopartikel $\mathrm{MgO}$, sol-gel combustion, evaluasi ekonomi, studi kelayakan

\begin{abstract}
The purpose of this study is to determine the feasibility of the project to make Magnesium Oxide $(\mathrm{MgO})$ sol gel combustion method by evaluating the engineering and economic aspects. Several economic evaluation parameters are analyzed to inform the potential production of $\mathrm{MgO}$ nanoparticles, such as the length of time required for an investment to recover the total initial expenditure $(P B P)$, project conditions for a production in the form of a production function in years $(C N P V)$, project profits and others. The results showed that the production of $M g O$ nanoparticles was very prospective. Technical analysis to produce $1.38 \mathrm{~kg}$ of $\mathrm{MgO}$ nanoparticles per day shows the total cost of the equipment purchased was USD 91,542.86. PBP analysis shows that investment profitable after more than three years. This project can compete with PBP capital market standards because the investment will return in a short time. To ensure the feasibility of the project, the project is estimated from the ideal conditions to the worst cases in production, including labor, sales, raw materials, utilities, and external conditions (e.g. tax).
\end{abstract}

Key Words : MgO nanoparticles, sol-gel combustion, economic evaluation, feasibility study

\section{PENDAHULUAN}

Magnesium oksida (MgO) merupakan bahan keramik yang potensial. $\mathrm{MgO}$ merupakan bahan keramik yang mempunyai titik lebur tinggi, sehingga bersifat tahan api, permukaan yang kuat, tahan air, kedap suara, tahan terhadap serangan jamur, lumut dan pembusukan. $\mathrm{MgO}$ memiliki sifat optik, listrik, termodinamik, elektronik dan mekanik yang sangat baik. $\mathrm{MgO}$ biasanya digunakan untuk pembuatan material sebagai dinding tahan panas pada furnace, isolator listrik, pembungkus makanan, kosmetik, pembuatan obat pada bidang farmasi [1], katalis [2], bactericidal properties [3], photocatalytic [4], adsorben [5], optical properties [6] dan biosensor elektrokimia [7]. 
Sintesis nanopartikel $\mathrm{MgO}$ dapat dilakukan dengan metode presipitasi [1], sol-gel combustion [8], sol-gel non aqueous [9], hidrotermal [10], mikro-emulsi [11], dan combustion [12]. Metode yang paling tepat untuk dilakukan analisis evaluasi ekonomi adalah metode sol gel combustion yang telah dilakukan oleh Nassar, dkk [8]. Proses ditunjukkan pada Gambar 1. Ini karena metode sol gel combustion memiliki skalabilitas dan kelayakan serta menggunakan bahan baku yang mudah didapat dan murah. Sedangkan metode sol gel non aqueous dilakukan oleh Athar, T., dkk., [9] metode ini tidak dipilih karena bahan baku yang digunakan bersifat karsinogenik dan mahal. Metode hidrotermal dilakukan oleh Ding, Y., dkk., [10] metode ini tidak dipilih karena mahal dan stoikiometri larutan sulit dikontrol [1].

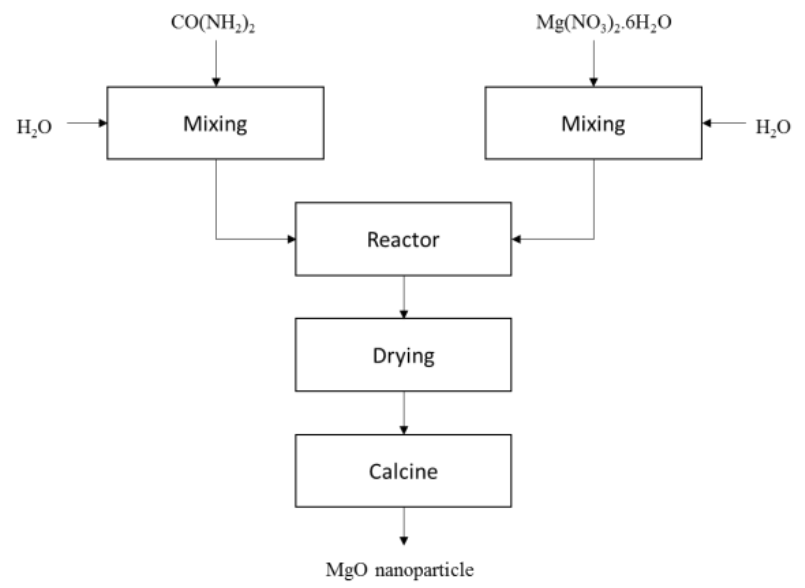

Gambar 1. Skema proses pembuatan MgO metode sol-gel combustion

Tujuan dari penelitian ini adalah untuk mengetahui kemungkinan kelayakan proyek pembuatan nanopartikel $\mathrm{MgO}$ metode sol gel combustion dengan melakukan evaluasi dari sisi teknik dan ekonomi. Ini karena belum ada artikel yang membahas secara detail mengenai evaluasi ekonomi dari sintesis nanopartikel $\mathrm{MgO}$. Pengubahan skala lab menjadi skala industri pada kuantitas bahan baku dan peralatan dilakukan untuk penelitian ini. Kami melakukan beberapa variasi ekonomi pada pajak, penjualan, bahan baku, tenaga kerja dan utilitas.

\section{METODE PENELITIAN}

Penelitian ini menggunakan metode berdasarkan pada analisis harga bahan, peralatan, dan spesifikasi peralatan yang tersedia secara komersial di web belanja online. Semua data dihitung berdasarkan perhitungan matematis sederhana menggunakan aplikasi Microsoft Excel. Parameter evaluasi ekonomi dilakukan untuk mengkonfirmasi evaluasi ekonomi dari proyek ini. Beberapa parameter evaluasi ekonomi digunakan berdasarkan literatur [8, 13, 14], parameter evaluasi ekonomi disajikan dalam rumus berikut:

(1) Gross profit margin (GPM) adalah analisis pertama untuk menentukan tingkat profitabilitas suatu proyek dengan mengurangi biaya penjualan produk dengan biaya bahan baku.

(2) Payback period (PBP) atau dana kembali adalah perhitungan yang dilakukan untuk memprediksi lamanya waktu yang dibutuhkan sebuah investasi agar bisa mengembalikan total pengeluaran awal. PBP dihitung ketika CNPV di titik nol untuk pertama kalinya.

(3) Break even point (BEP) adalah jumlah produk minimum yang harus dijual dengan harga tertentu untuk menutupi total biaya produksi. BEP dapat dihitung dengan cara menghitung nilai fixed cost dibagi dengan (total harga penjualan kurang total variable cost).

(4) Cumulative net present value (CNPV) adalah nilai yang memprediksi kondisi proyek suatu produksi dalam bentuk fungsi produksi dalam tahun. Nilai CPNV didapat dari net present value (NPV) pada waktu tertentu. NPV adalah nilai yang menyatakan pengeluaran dan pendapatan suatu usaha. Secara singkat, CNPV diperoleh dengan menambahkan nilai NPV dari pertama kali proyek sampai akhir oprasi pabrik. 
(5) Profitability index (PI) adalah indeks untuk mengidentifikasi hubungan antara biaya dan dampak proyek. PI dapat dihitung dengan membagi antara CNPV dengan total biaya investasi (TIC). Jika PI kurang dari satu, maka proyek dapat digolongkan sebagai proyek yang tidak menguntungkan dan jika PI lebih dari satu, maka proyek dapat digolongkan sebagai proyek yang baik.

Beberapa asumsi berdasarkan proses ditunjukkan pada Gambar 2. Asumsi ini menunjukkan perhitungan stoikiometri setelah meningkatkan proyek yang menghasilkan sekitar 1,38 kg nanopartikel $\mathrm{MgO}$. Asumsinya adalah:

(1) Semua komposisi kimia dalam reaksi, seperti magnesium nitrat heksahidrat, urea dan air suling digunakan untuk produksi nanopartikel $\mathrm{MgO}$. Bahanbahan tersebut ditingkatkan hingga 2000 kali. Bahan-bahan memiliki kemurnian tinggi. Bahan-bahan dihitung berdasarkan literatur [8].

(2) Magnesium nitrat heksahidrat dan urea direaksikan dengan perbandingan 6:10. Keduanya diasumsikan habis bereaksi menghasilkan magnesium oksida dengan kemurnian $99 \%$.

(3) Tingkat konversi untuk proses pembentukan magnesium oksida adalah $100 \%$.

(4) Kerugian dalam setiap proses pemindahan dari reaktor-3 ke pengeringan adalah $2 \%$, kerugian dari pengeringan ke penghalusan adalah $10 \%$, dan kerugian dari penghalusan adalah $2 \%$.

Beberapa asumsi digunakan untuk memastikan analisis ekonomi. Asumsi ini diperlukan untuk menganalisis dan memprediksi beberapa kemungkinan yang terjadi selama proyek. Asumsinya adalah:

(1) Semua analisis menggunakan mata uang USD. 1 USD = 14.000 rupiah [15].

(2) Berdasarkan harga yang tersedia secara komersial, harga Magnesium nitrat heksahidrat, urea dan aquades adalah $557,14 \mathrm{USD} / \mathrm{kg} ; 5,96 \mathrm{USD} / \mathrm{kg}$ dan 0,5
USD/L. Semua bahan diperkirakan berdasarkan stoikiometri [8].

(3) The total investment cost (TIC) dihitung berdasarkan Lang Factor [14].

(4) TIC disiapkan setidaknya dalam dua langkah. Langkah pertama adalah $40 \%$ di tahun pertama dan langkah kedua adalah sisanya (selama pembangunan proyek).

(5) Tanah dibeli. Dengan demikian, biaya tanah ditambahkan pada awal tahun konstruksi pabrik dan diperoleh kembali di akhir proyek.

(6) Penyusutan diestimasi menggunakan perhitungan langsung [14].

(7) Satu siklus proses pembuatan nanopartikel $\mathrm{MgO}$ membutuhkan waktu 10 jam.

(8) Biaya ongkos kirim dibebankan kepada pembeli.

(9) Biaya kemasan dibebankan kepada pembeli sebesar 0,143 USD/5 gram.

(10) Nanopartikel $\mathrm{MgO}$ dijual dengan harga 32 USD/pack (5 gram).

(11) Proyek satu tahun adalah 300 hari (dan sisanya adalah hari digunakan untuk membersihkan dan mengatur proses).

(12) Untuk menyederhanakan utilitas, unit utilitas dapat dijelaskan dan dikonversi sebagai unit listrik, seperti $\mathrm{kWh}$ [13]. Kemudian, unit listrik dikonversi menjadi biaya. Unit listrik (kWh) dikalikan dengan biaya listrik. Asumsi biaya utilitas adalah $0,1075 \mathrm{USD} / \mathrm{kWh}$.

(13) Total upah/tenaga kerja diasumsikan dengan nilai tetap sebesar 70 USD/hari.

(14) Tingkat diskon adalah $15 \%$ per tahun.

(15) Pajak penghasilan adalah $10 \%$ setiap tahun.

(16) Panjang operasi proyek adalah 20 tahun.

Evaluasi ekonomi dilakukan untuk uji kelayakan proyek. Evaluasi ekonomi ini dilakukan dengan variasi nilai pajak, penjualan, bahan baku, tenaga kerja dan utilitas dalam beberapa kondisi. Variasi pajak dilakukan pada $10,25,50,75$ dan 
$100 \%$. Variasi penjualan, bahan baku, tenaga kerja dan utilitas dilakukan pada 80 , 90, 100, 110 dan $120 \%$.

\section{HASIL DAN PEMBAHASAN Prespektif Teknik}

Gambar 2 menunjukkan proses pembuatan nanopartikel $\mathrm{MgO}$ dengan metode sol gel combustion berdasarkan literatur [8]. $\mathrm{MgO}$ disintesis dengan mencampurkan prekursor magnesium nitrat heksahidrat $\mathrm{Mg}\left(\mathrm{NO}_{3}\right)_{2} \cdot 6 \mathrm{H}_{2} \mathrm{O}$ dan urea $\mathrm{CO}\left(\mathrm{NH}_{2}\right)_{2}$. Massa $\mathrm{Mg}\left(\mathrm{NO}_{3}\right)_{2} \cdot 6 \mathrm{H}_{2} \mathrm{O}$ dan massa urea yang dibutuhkan untuk menghasilkan 1,38 $\mathrm{kg} \mathrm{MgO}$ nanopartikel adalah 10,24 kg dan 3,99 kg. Setiap bahan dilarutkan dalam aquades, total aquades yang diperlukan untuk kedua bahan adalah 140 liter. Masing-masing larutan dimasukkan ke dalam reaktor. Campuran tersebut diaduk menggunakan pengaduk otomatis. Campuran direaksikan pada suhu $70^{\circ} \mathrm{C}$ sampai larutan tersebut kental. Kapasitas reaktor adalah 200 liter. Cairan kental tersebut dimasukkan ke dalam furnace. Cairan kental dikalsinasi pada suhu $550^{\circ} \mathrm{C}$. Kapasitas furnace adalah 198 liter dengan pengoprasian suhu pada 400 sampai $1400^{\circ} \mathrm{C}$. Sampel $\mathrm{MgO}$ dihaluskan dengan alat khusus penghalus mekanik powder untuk mendapatkan ukuran nanopartikel. Mekanisme reaksi yang terjadi selama proses sintesis adalah:

$6 \mathrm{Mg}\left(\mathrm{NO}_{3}\right)_{2} \cdot 6 \mathrm{H}_{2} \mathrm{O}_{(\mathrm{aq})}+10 \mathrm{CO}\left(\mathrm{NH}_{2}\right)_{2(\mathrm{aq})} \rightarrow$ $6 \mathrm{MgO}_{(\mathrm{s})}+13 \mathrm{~N}_{2(\mathrm{~g})}+10 \mathrm{CO}_{2(\mathrm{~g})}+38 \mathrm{H}_{2} \mathrm{O}_{(\mathrm{g})}$ (1)

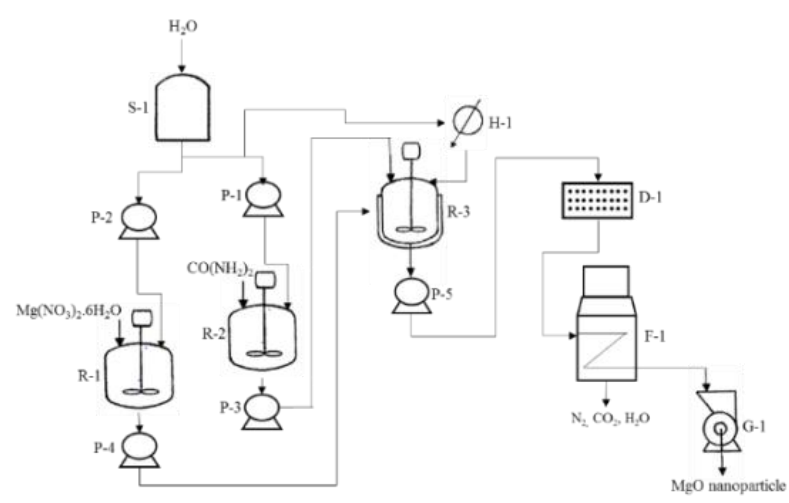

Gambar 2. Proses flow diagram MgO
Tabel 1. Tabel proses flow diagram

\begin{tabular}{ccc}
\hline No & Simbol & Informasi \\
\hline 1. & S-1 & Storage-1 \\
2. & $\mathrm{P}-1$ & Pump-1 \\
3. & $\mathrm{P}-2$ & Pump -2 \\
4. & $\mathrm{P}-3$ & Pump -3 \\
5. & $\mathrm{P}-4$ & Pump -4 \\
6. & $\mathrm{P}-5$ & Pump -5 \\
7. & $\mathrm{R}-1$ & Reactor -1 \\
8. & $\mathrm{R}-2$ & Reactor-2 \\
9. & $\mathrm{R}-3$ & Reactor-3 \\
10. & $\mathrm{H}-1$ & Heater -1 \\
11. & $\mathrm{D}-1$ & Drying oven-1 \\
12. & $\mathrm{~F}-1$ & Furnace-1 \\
13. & $\mathrm{G}-1$ & Grinding-1 \\
\hline
\end{tabular}

Satu siklus menghasilkan nanopartikel $\mathrm{MgO}$ sebanyak $1,38 \mathrm{~kg}$. Dalam satu tahun, proyek dapat memproduksi nanopartikel $\mathrm{MgO}$ sebesar $414 \mathrm{~kg}$. Hasil produk samping seperti nitrogen, karbon dioksida dan uap air dibuang. Hasil produk samping tidak digunakan.

Berdasarkan sudut pandang teknik, Peningkatan analisis dapat dilakukan. Peningkatan tersebut terjadi karena proses penskalaan dapat diimplementasikan menggunakan peralatan yang tersedia secara komersial dan murah. Selain itu untuk menghitung proyek dengan 300 siklus pemrosesan per tahun, skema yang disarankan adalah prospektif untuk menghasilkan sekitar 0,414 ton $\mathrm{MgO}$ dengan mengonsumsi 3,072 ton $\mathrm{Mg}\left(\mathrm{NO}_{3}\right)_{2} \cdot 6 \mathrm{H}_{2} \mathrm{O}, 1,199$ ton urea dan 42 ton liter air per tahun dalam kondisi ideal. Total biaya yang harus dibayarkan untuk bahan baku selama satu tahun adalah 1.739.845,10 USD. Penjualan dalam satu tahun adalah 2.649.600,00 USD. Keuntungan diperoleh sebesar 909.754,90 USD atau setara dengan 52\%. Kemudian, analisis total biaya peralatan membutuhkan total biaya sebesar 91.542,86 USD. Faktor Lang ditambahkan ke dalam perhitungan. TIC harus kurang dari 406.450,29 USD. Nilai ini relatif ekonomis. Proyek ini membutuhkan dana investasi lebih sedikit. Masa hidup proyek selama 20 tahun menghasilkan 0,414 ton nanopartikel $\mathrm{MgO}$ dengan CNPV/TIC mencapai 5,13\% 
pada tahun ke-20 dan PBP tercapai pada tahun ke-3.

\section{Evaluasi Ekonomi}

\section{Kondisi Ideal}

Gambar 3 menunjukkan grafik hubungan antara CNPV/TIC terhadap waktu. Sumbu $\mathrm{y}$ adalah CNPV/TIC dan sumbu $\mathrm{x}$ adalah life time (year). Grafik menunjukkan penurunan pendapatan pada tahun ke-1 sampai ke-2, ini karena adanya biaya modal awal seperti alat yang diperlukan selama proses produksi nanopartikel $\mathrm{MgO}$ serta tanah yang dibeli. Pada tahun ke-3 grafik menunjukkan kenaikan pendapatan, kondisi ini adalah Payback Period (PBP). Keuntungan dapat menutupi modal awal yang telah dihabiskan dan keuntungan terus meningkat setelahnya sampai tahun ke-20. Dengan demikian, produksi nanopartikel $\mathrm{MgO}$ dapat dianggap sebagai proyek menguntungkan karena proyek ini memerlukan waktu singkat untuk memulihkan biaya investasi sejak PBP hanya sekitar 3 tahun. Proyek ini adalah ideal untuk dijalankan dalam produksi industri . Hasil analisis PBP dari kondisi ideal telah dilakukan oleh Sudaryanto, S., dkk. Hasil analisis PBP mengungkapkan titik dimana modal dapat kembali lebih kecil dari umur rencana proyek dikatakan menguntungkan [16].

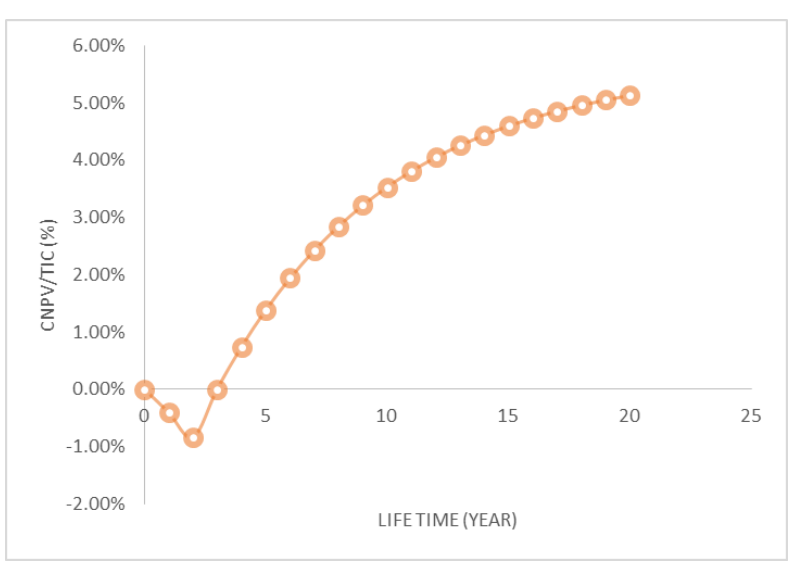

Gambar 3. Kondisi ideal CNPV/TIC terhadap life time (year)

\section{Pengaruh Kondisi Eksternal}

Faktor eksternal dapat mempengaruhi keberhasilan suatu proyek. Salah satu faktor eksternal yang paling berpengaruh adalah pungutan lain yang dibebankan pada proyek oleh negara untuk membiayai berbagai pengeluaran publik.

Gambar 4 menunjukkan grafik CNPV dengan berbagai variasi pajak. Sumbu y adalah CNPV/TIC dan sumbu $x$ adalah life time (year). PBP diperoleh dari variasi pajak. Seperti yang ditunjukkan dalam Gambar 4, kondisi awal (dari 0 hingga 2 tahun proyek) dari CNPV di bawah berbagai variasi pajak adalah sama. Ini karena adanya pembangunan proyek. Pengaruh pajak atas CNPV dapat diperoleh setelah proyek dibuat (dari 2 tahun). Ketika biaya pajak ditambahkan ke proyek, keuntungan proyek menurun. Untung ini terkait dengan proyek PBP.

Berdasarkan analisis PBP, dana kembali ketika pajak yang harus dibayar sebesar 10, 25, 50, 75 dan $100 \%$ secara berturut-turut tercapai pada tahun ke-3; 3,5; 4; 6,5 dan tidak tercapai PBP. Keuntungan terus meningkat setalah mencapai titik Payback Period (PBP) sampai tahun ke-20. Namun, jarak keuntungan dihasilkan untuk setiap tahun makin sedikit seiiring dengan kenaikan pajak dan rugi ketika pajak yang harus dibayar $100 \%$ dari kondisi ideal. Nilai CNPV/TIC pada tahun ke-20 untuk setiap variasi $10,25,50,75$ dan $100 \%$ adalah 5,$13 ; 4,16 ; 2,55 ; 0,95$ dan $-0,66 \%$. Jadi, pajak maksimum untuk mendapatkan BEP (titik dimana baik keuntungan maupun kerugian dalam proyek) adalah $75 \%$. Perubahan pajak hingga lebih dari $75 \%$ membuat kegagalan dalam proyek. Hasil analisis grafik CNPV/TIC dari variasi pajak dilakukan oleh Nandiyanto, A. B. D. Hasil analisis mengungkapkan bahwa semakin banyak pajak yang ditambahkan ke proyek (ditunjukkan oleh titik-titik yang jelas; dari 0 hingga $65 \%$ ) menghasilkan lebih sedikit manfaat yang diperoleh [13]. 


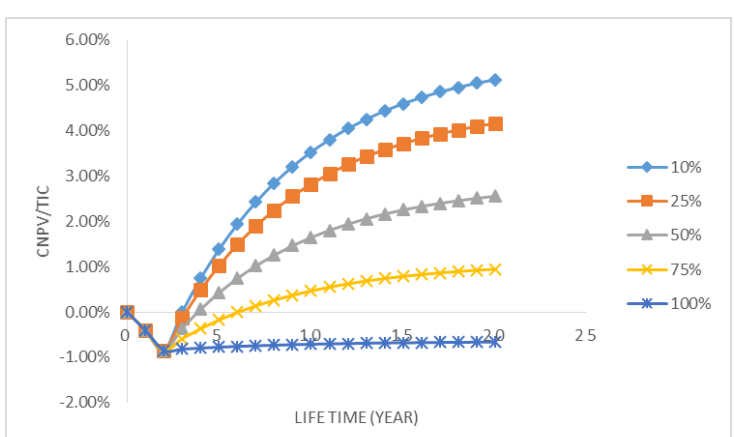

Gambar 4. Kurva CNPV variasi pajak

\section{Perubahan Penjualan}

Gambar 5 menunjukkan grafik CNPV dengan berbagai variasi penjualan. Sumbu $\mathrm{y}$ adalah CNPV/TIC dan sumbu $\mathrm{x}$ adalah life time (year). Analisis dilakukan dengan meningkatkan dan menurunkan penjualan sebesar 10 dan 20\%. Penjualan ideal adalah $100 \%$, ketika penjualan diturunkan 10 dan $20 \%$ maka penjualan berturut-turut menjadi 90 dan $80 \%$. Ketika penjualan dinaikkan 10 dan $20 \%$ maka penjualan menjadi 110 dan $120 \%$.

PBP diperoleh dari variasi penjualan. Hasil PBP ditunjukkan dalam Gambar 5. Kondisi awal (dari 0 hingga 2 tahun proyek) dari CNPV di bawah berbagai variasi penjualan adalah sama. Ini karena adanya pembangunan proyek. Pengaruh penjualan terhadap CNPV dapat diperoleh setelah proyek dibuat (dari 2 tahun). Makin besar nilai penjualan maka keuntungan makin meningkatkan dari proyek yang dikerjakan. Tetapi, apabila ada kondisi yang menyebabkan penjualan produk menurun maka keuntungan proyek berkurang dari keadaan ideal.

Berdasarkan analisis PBP, dana kembali ketika variasi penjualan sebesar 120,110 , 100, 90 dan $80 \%$ secara berturut-turut dicapai pada tahun ke-2,5; 2,75; 3; 4 dan tidak tercapai PBP. Keuntungan terus meningkat setalah mencapai titik Payback Period (PBP) sampai tahun ke-20. Namun, jarak keuntungan dihasilakan untuk setiap tahunnya makin sedikit seiiring dengan penurunan penjualan dan rugi ketika penjualan diturunkan sebesar $20 \%$ dari kondisi ideal. Sebaliknya, jarak keuntungan dihasilkan untuk setiap tahunnya makin meningkat dengan peningkatan penjualan dari kondisi ideal. Nilai CNPV/TIC pada tahun ke-20 untuk setiap variasi $120,110,100,90$ dan $80 \%$ adalah 10,$56 ; 7,85 ; 5,13 ; 2,14$ dan $-0,31 \%$. Jadi, penjualan minimum untuk mendapatkan BEP (titik dimana baik keuntungan maupun kerugian dalam proyek) adalah $90 \%$. Perubahan penjualan hingga kurang dari $90 \%$ membuat kegagalan dalam proyek. Seperti pada penjualan nanopartikel Co menguntungkan jika penjualan dinaikkan lebih dari $100 \%$ karena grafik menunjukkan nilai CNPV/TIC yang positif, ini berarti proyek tersebut layak untuk dijalankan [17].

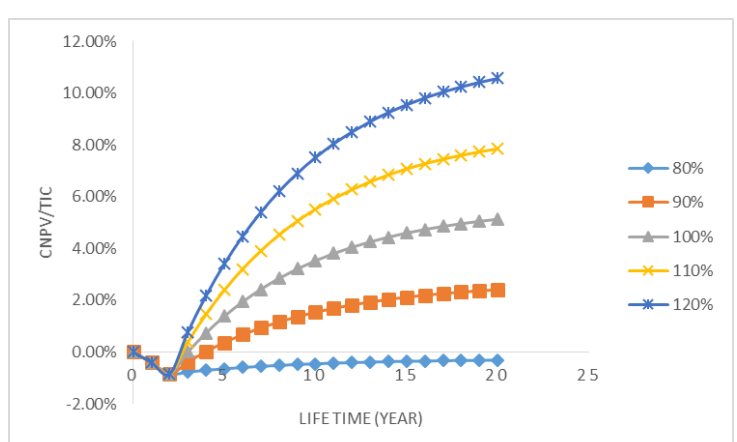

Figure 5. Kurva CNPV variasi penjualan

\section{Perubahan variable cost (bahan baku, tenaga kerja, utilitas)}

Terdapat faktor internal seperti kondisi bahan baku, tenaga kerja dan utilitas yang dapat mempengaruhi keberhasilan suatu proyek. Gambar 6 menunjukkan grafik CNPV dengan berbagai variasi bahan baku. Sumbu y adalah CNPV/TIC dan sumbu $\mathrm{x}$ adalah life time (year). Analisis dilakukan dengan menurunkan dan menaikkan bahan baku sebesar 10 dan $20 \%$. Bahan baku ideal adalah 100\%, ketika bahan baku diturunkan 10 dan $20 \%$ maka bahan baku berturut-turut menjadi 90 dan $80 \%$. Ketika bahan baku dinaikkan 10 dan $20 \%$ maka bahan baku menjadi 110 dan $120 \%$.

PBP diperoleh dari hasil variasi bahan baku. Hasil PBP ditunjukkan dalam 
Gambar 6. Kondisi awal (dari 0 hingga 2 tahun proyek) dari CNPV di bawah berbagai variasi bahan baku adalah sama. Ini karena adanya pembangunan proyek. Pengaruh bahan baku atas CNPV dapat diperoleh setelah proyek dibuat (dari 2 tahun). Makin kecil bahan baku maka keuntungan proyek makin meningkatkan. Tetapi, apabila ada keadaan yang menyebabkan bahan baku meningkat maka keuntungan proyek berkurang dari keadaan ideal.

Berdasarkan analisis PBP, dana kembali ketika variasi bahan baku sebesar 80, 90, 100, 110 dan $120 \%$ secara berturut-turut tercapai pada tahun ke-2,5; 2,75; 3; 3,5 dan 5. Keuntungan terus meningkat setelah mencapai titik Payback Period (PBP) sampai tahun ke-20. Namun, jarak keuntungan yang diperoleh setiap tahunnya makin sedikit dengan kenaikan bahan baku dari kondisi ideal. Sebaliknya, jarak keuntungan yang diperoleh setiap tahunnya makin meningkat dengan penurunan bahan baku dari kondisi ideal. Nilai CNPV/TIC pada tahun ke-20 untuk setiap variasi $80,90,100,110$ dan $120 \%$ adalah 8,$70 ; 6,91 ; 5,13 ; 3,34$ dan 1,56\%. Dari variasi bahan baku, proyek masih bisa berjalan dan mendapatkan keuntungan.

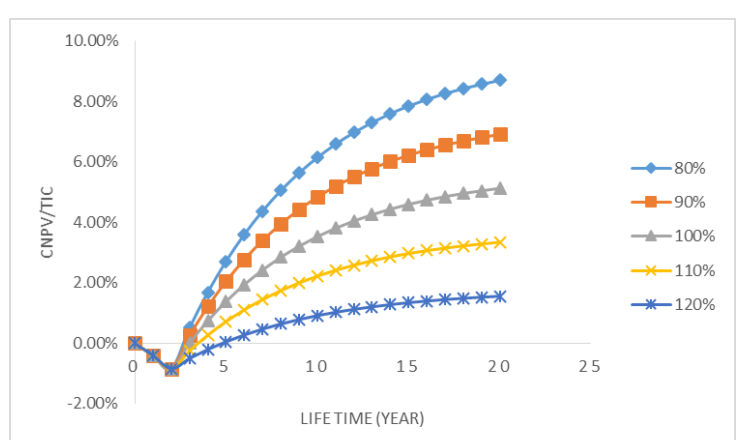

\section{Gambar 6. Kurva CNPV variasi bahan baku}

Gambar 7 menunjukkan grafik CNPV dengan berbagai variasi tenaga kerja. Sumbu y adalah CNPV/TIC dan sumbu $\mathrm{x}$ adalah life time (year). Analisis dilakukan dengan meningkatkan dan menurunkan tenaga kerja sebesar 10 dan 20\%. Gaji tenaga kerja ideal adalah $100 \%$, ketika gaji tenaga kerja diturunkan 10 dan $20 \%$ maka gaji tenaga kerja berturut-turut menjadi 90 dan $80 \%$. Ketika gaji tenaga kerja dinaikkan 10 dan $20 \%$ maka gaji tenaga kerja menjadi 110 dan $120 \%$. PBP diperoleh dari hasil variasi gaji tenaga kerja. Hasil PBP ditunjukkan dalam Gambar 7. Kondisi awal (dari 0 hingga 2 tahun proyek) dari CNPV di bawah berbagai variasi gaji tenaga kerja adalah sama. Ini karena adanya pembangunan proyek. Pengaruh tenaga kerja atas CNPV dapat diperoleh setelah proyek dibuat (dari 2 tahun). Tidak terjadi perubahan yang signifikan dari kurva variasi tenaga kerja terhadap grafik CNPV. PBP disetiap variasi tenaga kerja tetap tercapai pada tahun ke-3. Namun, nilai CNPV/TIC mengalami perbedaan pada tahun ke-20 untuk setiap variasi. Perbedaan nilai tersebut untuk setiap variasi $80,90,100$, 110 dan $120 \%$ adalah 5,$17 ; 5,15 ; 5,13$; 5,11 dan $5,08 \%$. Dari variasi tenaga kerja, proyek masih bisa berjalan dan mendapatkan keuntungan.

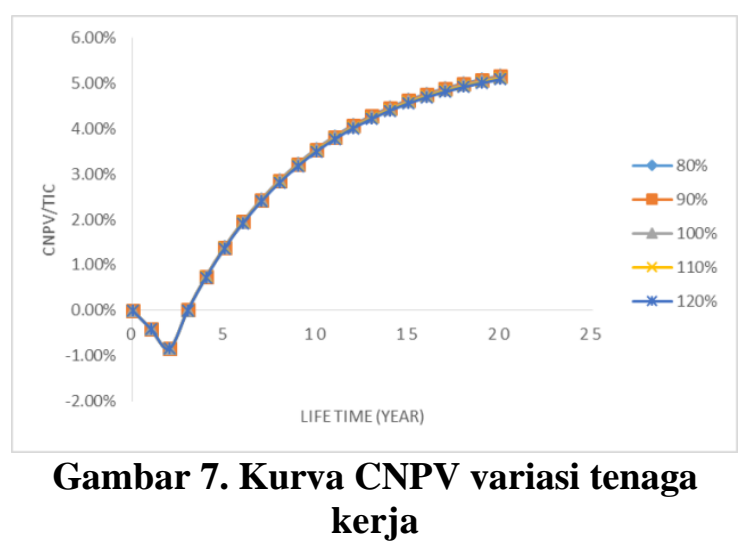

Gambar 8 menunjukkan grafik CNPV dengan berbagai variasi utilitas. Sumbu y adalah CNPV/TIC dan sumbu $\mathrm{x}$ adalah life time (year). Analisis dilakukan dengan meningkatkan dan menurunkan harga utilitas sebesar 10 dan 20\%. Biaya utilitas ideal adalah $100 \%$, ketika utilitas diturunkan 10 dan 20\% maka utilitas 
berturut-turut 90 dan $80 \%$. Ketika utilitas dinaikkan 10 dan $20 \%$ maka utilitas 110 dan $120 \%$.

PBP diperoleh dari hasil variasi utilitas. Hasil PBP ditunjukkan dalam Gambar 7. Kondisi awal (dari 0 hingga 2 tahun proyek) dari CNPV di bawah berbagai variasi utilitas adalah sama. Ini karena adanya pembangunan proyek. Pengaruh utilitas terhadap CNPV dapat diperoleh setelah proyek dibuat (dari 2 tahun). Tidak terjadi perubahan yang signifikan dari variasi utilitas terhadap grafik CNPV. Namun, nilai CNPV/TIC mengalami perbedaan pada tahun ke-20 disetiap variasi. Perbedaan nilai tersebut untuk setiap variasi $80,90,100,110$ dan $120 \%$ adalah 5,$17 ; 5,15 ; 5,13 ; 5,10$ dan $5,08 \%$. PBP disetiap variasi utilitas tetap tercapai pada tahun ke-3. Dari variasi utilitas, proyek masih bisa berjalan dan mendapatkan keuntungan.

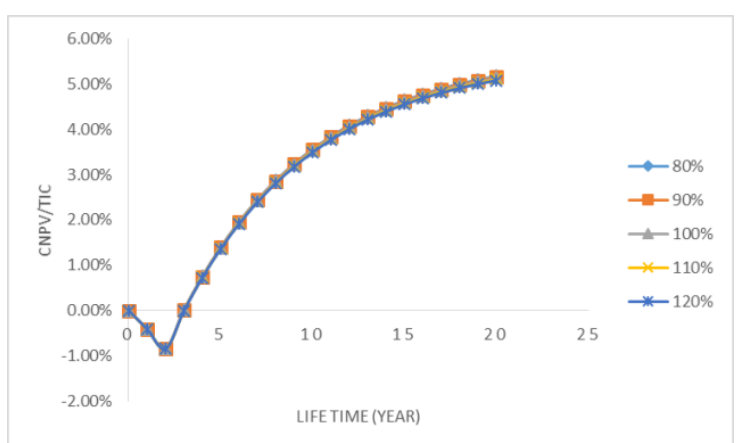

Gambar 8. Kurva CNPV variasi utilitas

Berdasarkan analisis di atas, proyek dalam kondisi ideal adalah prospektif. Proyek pembuatan nanopartikel $\mathrm{MgO}$ hanya menguntungkan dalam kondisi ekonomi tertentu ketika ada perubahan dalam keadaan ekonomi. Proyek merugi jika proyek dilakukan dalam keadaan di luar kondisi ekonomi tertentu. Berikut ini adalah penjelasan tentang kondisi spesifik:

(1) Pajak berpengaruh terhadap keuntungan proyek. Pajak harus diperkirakan dengan jelas karena pajak maksimum untuk mempertahankan proyek harus kurang dari $75 \%$.
(2) Penjualan harus dipertahankan dalam kisaran lebih tinggi dari $90 \%$. Ketika penjualan kurang dari $90 \%$, proyek gagal.

(3) Perubahan harga bahan baku dengan variasi $80,90,100,110$, dan $120 \%$ berdampak pada keuntungan yang diperoleh disetiap tahunnya. Proyek masih bisa berjalan, namun proyek mendapatkan keuntungan yang sedikit ketika harga bahan baku lebih dari $100 \%$.

(4) Biaya tenaga kerja dengan variasi $80,90,100,110$, dan $120 \%$ tidak berpengaruh terhadap keuntungan yang diperoleh. Ini karena presentase pengeluaran untuk biaya tenaga kerja sekitar $0,03 \%$ dari keuntungan.

(5) Utilitas (biaya listrik) dengan variasi $80,90,100,110$, dan $120 \%$ tidak berpengaruh terhadap keuntungan yang diperoleh. Ini karena presentase pengeluaran untuk biaya tenaga kerja sekitar $0,03 \%$ dari keuntungan.

(6) Analisis variasi variable cost dilakukan oleh Nandiyanto, A., [13] dan Nandatamadini, F., dkk [17]. Mereka menyatakan hasil analisis variasi variable cost memainkan peran penting dalam laba, penurunan variable cost mempengaruhi nilai tinggi CNPV akhir. Terkait dengan meningkatnya variable cost, proyek akan mengalami kerugian. Tetapi ketika menggunakan nilai variable cost yang lebih rendah, proyek lebih efektif menghasilkan lebih banyak keuntungan. Singkatnya, variable cost yang lebih rendah efektif untuk menghasilkan lebih banyak keuntungan. Namun, untuk kasus peningkatan variable cost, proyek akan hilang. Dalam hasil penelitian ini variable cost yang paling berpengaruh adalah biaya bahan baku. Ini dilihat dari perubahan setiap kurva pada grafik CNPV.

Selain prospek ekonomis, analisis daya tarik harus dilakukan. Proyek ini menjadi prespektif yang kurang menarik bagi investor industri. Prespektif ini merujuk pada pasar modal standar Indonesia [13]. 
Dalam kasus CNPV akhir, nilai CNPV akhir tidak cukup tinggi untuk proyek selama 20 tahun. Nilai CNPV akhir per tahun relatif kurang. Ini juga diperkuat dari nilai PI yang relatif rendah. Analisis PBP menunjukkan kondisi yang kompetitif. Ini dilihat berdasarkan pasar modal standar untuk 25.000 USD biasanya mempromosikan PBP sekitar 1-2 tahun [13]. Namun, investasi jangka panjang yang khas ini tidak menarik bagi investor.

Selain itu, penelitian ini tidak menunjukkan proses rekayasa baru. Namun, ide baru dalam penelitian ini adalah untuk memberikan informasi dan pengetahuan tentang kelayakan untuk produksi $\mathrm{MgO}$ nanopartikel.

\section{SIMPULAN}

Berdasarkan analisis di atas, proyek produksi nanopartikel $\mathrm{MgO}$ metode sol-gel combustion yang prospektif dari sudut pandang teknik dan cukup menjanjikan dalam evaluasi ekonomi. Analisis PBP menunjukkan bahwa investasi menguntungkan setelah lebih dari 3 tahun. Proyek ini dapat bersaing dengan standar pasar modal PBP karena investasi kembali dalam waktu singkat. Beberapa hal yang mempengaruhi manfaat ini termasuk menggunakan metode sol-gel combustion, karena metode ini sangat mudah dan murah. Dari analisis evaluasi ekonomi ini, kami dapat menyimpulkan bahwa proyek ini layak untuk dijalankan.

\section{DAFTAR PUSTAKA}

[1] Alvionita, N., \& Astuti, A. (2017). Sintesis Nanopartikel Magnesium Oksida (MgO) dengan Metode Presipitasi. Jurnal Fisika Unand, 6(1), 89-92.

[2] Yuan, G., Zheng, J., Lin, C., Chang, X., \& Jiang, H. (2011). Electrosynthesis and catalytic properties of magnesium oxide nanocrystals with porous structures.
Materials Chemistry and Physics, 130(1-2), 387-391.

[3] Zhang, K., An, Y., Zhang, L., \& Dong, Q. (2012). Preparation of controlled nano-MgO and investigation of its bactericidal properties. Chemosphere, 89(11), 1414-1418.

[4] Mantilaka, M. P. G., De Silva, R. T., Ratnayake, S. P., Amaratunga, G., \& de Silva, K. N. (2018). Photocatalytic activity of electrospun $\mathrm{MgO}$ nanofibres: synthesis, characterization and applications. Materials Research Bulletin, 99, 204-210.

[5] Mahmoud, H. R., Ibrahim, S. M., \& El-Molla, S. A. (2016). Textile dye removal from aqueous solutions using cheap $\mathrm{MgO}$ nanomaterials: adsorption kinetics, isotherm studies and thermodynamics. Advanced Powder Technology, 27(1), 223-231.

[6] Stankic, S., Muller, M., Diwald, O., Sterrer, M., Knozinger, E., \& Bernardi, J. (2005). Size-dependent optical properties of $\mathrm{MgO}$ nanocubes. Angewandte Chemie International Edition, 44(31), 4917-4920.

[7] Umar, A., Rahman, M. M., \& Hahn, Y. B. (2009). MgO polyhedral nanocages and nanocrystals based glucose biosensor. Electrochemistry Communications, 11(7), 1353-1357.

[8] Nassar, M. Y., Mohamed, T. Y., Ahmed, I. S., \& Samir, I. (2017). MgO nanostructure via a sol-gel combustion synthesis method using different fuels: an efficient nano-adsorbent for the removal of some anionic textile dyes. Journal of Molecular Liquids, 225, 730-740.

[9] Athar, T., Hakeem, A., \& Ahmed, W. (2012). Synthesis of $\mathrm{MgO}$ nanopowder via non aqueous sol-gel method. Advanced Science Letters, 7(1), 27-29.

[10]Ding, Y., Zhang, G., Wu, H., Hai, B., Wang, L., \& Qian, Y. (2001). 
Nanoscale magnesium hydroxide and magnesium oxide powders: control over size, shape, and structure via hydrothermal synthesis. Chemistry of materials, 13(2), 435-440.

[11]Li, S., Zhou, B., Ren, B., Xing, L., Tan, L., Dong, L., \& Li, J. (2016). Preparation of $\mathrm{MgO}$ nanomaterials by microemulsion-based oil/water interface precipitation. Materials Letters, 171, 204-207.

[12] Granados-Correa, F., BonifacioMartínez, J., Lara, V. H., Bosch, P., \& Bulbulian, S. (2008). Cobalt sorption properties of $\mathrm{MgO}$ prepared by solution combustion. Applied Surface Science, 254(15), 4688-4694.

[13] Nandiyanto, A. B. D. (2018). Cost analysis and economic evaluation for the fabrication of activated carbon and silica particles from rice straw waste. Journal of Engineering Science and Technology, 13(6), 1523-1539.
[14] Garrett, D. E. (2012). Chemical engineering economics. Springer Science \& Business Media.

[15] Bank Indonesia. (2018) "Foreign Exchange Rates". [Online]. Available: https://www.bi.go.id/en/moneter/infor masi-kurs/referensi-jisdor/

[16] Sudaryanto, S., \& Agustinus, E. T. S. (2006). Tekno Ekonomi Produksi Glasir Berbahan Baku Tufa Andesitik Palimanan. Riset Geologi Dan Pertambangan, 16(1), 9-23.

[17] Nandatamadini, F., Karina, S., \& Nandiyanto, A. B. D. Feasibility Study Based On Economic Perspective Of Cobalt Nanoparticle Synthesis With Chemical Reduction Method. Cakra Kimia (Indonesian E-Journal Of Applied Chemistry), 7(1), 61-68 